\title{
The Argumentative Writing Skill with Multicultural Awareness in Indonesian Language for Foreign Learners
}

\author{
Kundharu Saddhono \\ Sebelas Maret University, Indonesia \\ Email: kundharu.uns@gmail.com \\ Tel: +6271-663485; Fax: +6271-663485
}

\begin{abstract}
Goals in this research are improving the quality and the skills of learning to write The Argumentative Writing Skill with Multicultural Awareness In Indonesian Language for Foreign Learners at Sebelas Maret University. This research conducted in the form of classroom action research. The research is the result of collaboration between researchers and teachers to improve the quality of learning. There are three data sources used as the object of data collection and information in this research. Those data sources are informant, event, and document. Technique in collecting the data used as the tools to gather the data in relation with the problem being investigated are observation, interview, tests, analysis of documents. The analysis technique used to analyze the data that has been collected is a comparative descriptive analysis techniques and critical analysis techniques. Analysis of data by comparing the test scores among cycles with predefined indicators work. The result of research showed that, the application of cooperative learning model in enhancing the argumentative writing skill with multicultural awareness in Indonesian language for foreign learners able to increase the quality process of learning to write argumentation multicultural perspective. This study also can improve the writing skills of multicultural-minded argumentations, at pre-action, the cycleI, the cycle II, and the cycle III.
\end{abstract}

Keywords: writing argumentation, multicultural, cooperative learning, Indonesian Language for Foreign Learners

\section{Introduction}

Sebelas Maret University (UNS) as one of the best universities in Indonesia must always strive to be a world-class university. Currently UNS into the top 10 best universities in Indonesia version of the Ministry of Research, Technology and Higher Education. As according 4ICU, UNS rank fourth after the Bandung Institute of Technology, Gadjah Mada University, and the University of Indonesia. One indicator is the number of foreign students studying in UNS. In 2015, more than 91 foreign students from 34 countries studying at the UNS from different continents of the world (Rector Anniversary Report 2016). UNS also one of the universities in Indonesia that provides a scholarship program, a program for foreigners to learn about the language and culture of Indonesia. In 2015, UNS receives about 35 foreign students in Darmasiswa Program and other programs.

Foreign students are required to master Indonesian language for educational purposes. The use of Indonesian language in the realm of education has been regulated in UU No. 24 Year 2009 regarding Flag, Language, and the State Emblem and Anthem precisely in Article 29 paragraph (1) which states that the Indonesian language shall be used as the language of instruction in the national education. By mastering the Indonesian language, they will be easier to communicate both orally and in written communication, especially to complete 
academic assignments on campus. Most of the tasks that they have got is writing skills. Writing is lowered or symbols depicting a graph illustrating a language that can be understood by a person so that others can read and understand the symbols of the graph. Writing is a language skill that is used to communicate indirectly. One of the skills taught to write is writing argumentative essay.

Argumentative essay is writing product which consists of explaining reasons and synthesizing opinions to build a conclusion (Suparno and Jonah, 2006: 5). Djuharie and Suherli (2005: 51) state that the argument is the text that expresses thinking, opinions, and ideas including reasons to convince others of the notion, the idea of the opinions expressed. The same opinion is conveyed by Sadhono and Slamet (2014: 160) who relate to writing arguments. In argument, the author expects the reader's justification of his opinion that there is an element in opinions, data, and facts or reasons underpinning the opinion. In describing, the argument must be objective and would be better equipped multicultural vision as the basis. Multicultural vision of argumentative writing is a form of writing argumentative containing elements of cultural diversity, ethnicity, religion and race which is objective and does not contain issue dealing with ethnic, religion, and race.

Based upon the foregoing description has been presented above, the vision of multicultural education is considered necessary to be taught in BIPA (Indonesian Language for Foreign Learners). Vision of multicultural education is a cutting-edge phenomenon which its existence is essential approached in a variety of perspectives. This is due to the paradigm of multicultural education benefits to build inter-ethnic solidarity, race, religion and culture. In line with this, Hilda Hernadez (in Mahfud, 2008: 176) argues that the education space as a medium for the transformation of science should be able to give the values of multiculturalism by way of mutual respect and respect for the reality of a plural, both background and socio-cultural base surrounding .

Based on the information obtained from the lecturer of BIPA UNS and observations in the process of teaching and learning writing, it is known that the process of learning to write is not maximized because the learning process is less attractive. It can be seen during apperception process conducted by the lecturer in the beginning of the lesson, students paid less attention and some students seemed not ready to follow the lesson. When professors had entered the material, students still looked out of focus and concentration on learning materials. By the time professors assigned the task of writing, only a few students who really did exist. Students who choose to write were not in accordance with the instructions of the lecturer. In learning process, lecturers still use the conventional method of learning resources that are not interesting, and learning does not refer to the lesson plan.

Based on the interview, conclusion can be drawn that the students were less interested in the learning process. It because the lecturer was less attractive and tend to be boring in delivering learning materials. In addition, students also had no motivation to keep learning. Another aspect comes from professors who did not provide an interesting learning material and still used conventional method. Therefore, models and media were failed to promote effective learning. Lecturers had not been up to provide motivation and guidance or examples of the use of diction and form of the word to be applied in argumentative writing. As a result, students were difficult to distinguish diction or word form that is right or not. Students also found that argumentative was not easy to write because they had trouble in expressing ideas in their minds in the form of a sentence.

Other factors that affect the learning process, apart from the factor of lecturer and students are learning environmental factors. Learning is an activity that requires concentration and comfort. Facilitating place and a comfortable learning environment are needed for the 
students to concentrate. By providing the right environment, the students will get better results and be able to enjoy the learning process that the students do (Yamin, 2011: 297). From the results of observations conducted by researcher, it was known that BIPA's learning environment was not conducive. This was due to the hectic atmosphere around the class. It was often disturbed by noise coming from the other classes. In addition, less strategic class position also made students look less comfortable in learning. Fortunately, the media was used optimally so that the learning process is going well.

In connection with the implementation of pre-cycle, it can be seen that the results of BIPA students' writing was still relatively low. The implementation of pre-cycle argumentative writing showed that out of 10 students only 2 people (20\%) reached the standard minimum score, which is 70 . The score of 8 people $(80 \%)$ was still below the standard minimum score of 70 . There were students who had reached the standard minimum score, but the skills and results of students' argumentative writing could be increased to achieve the target of at least $80 \%$ of students mastery with established criteria. After seeing the results of student writing, there were still many students who had not been able to write using a corect form of words or proper diction and good sentence structure.

The argumentative writing activities in this study were synergized with the multicultural aspect. It is based on the consideration that through multicultural education, students who come from different backgrounds led countries to know each other ways of life, customs, habits, understand the aspirations, as well as to recognize and respect that each group has the right to express themselves in their way respectively (Hashim and Hartono, 2008: 8-9). Multicultural education is very important to be applied in order to minimize and prevent conflict. Maslikhah (2007: 159) states that multicultural education as an alternative model should be developed and used as a model for education in BIPA based on several reasons:, first, that the reality of the students coming from different countries with diversity of ethnic, national, and religious bring culture and heterogeneous tradition. Second, the plurality is inherently already there before. Third, public education against business-oriented, commercialization, and prioritizes capitalist class. Fourth, the public does not want violence and arbitrariness of the implementation of the right of every person. Fifth, multicultural education is resistance fanaticism that leads to various types of violence, and abuse. Sixth, multicultural education gives hope to overcome the turmoil of society. Seventh, the terms multicultural education with human values, social, of nature, and deity.

Based on the above conditions, it inspires researcher to improve the argumentative writing skills of students at BIPA UNS by applying more effective and actively engage students learning model, cooperative learning model. The reasons of choosing this model are because it offers the emphasizing of learning processes and learning outcomes and it also trains students to dare to express an opinion (discussion) that is suitable for teaching writing, especially argumentative writing. This statement is in accordance with the opinion of Huda (2012: 33) who states that the positive consequences of cooperative learning is the students are given the freedom to be actively involved in their group. In a cooperative learning environment, students must be active participants and over group, can build a learning community that helps each other. Cooperative learning have a member of the group who are heterogeneous, meaning that groups are formed based on the differences in background, ethnicity, race, religion, socioeconomic status, and academic skills (Sugiyanto, 2009: 40). Based on the above condition, it is believed that cooperative learning model can improve the students' skills of argumentative writing for multicultural students at BIPA UNS. 


\section{Methodology}

There are several reasons why this research was conducted at BIPA UNS, namely: (1) based on the results of preliminary observations and interviews, it reveals any obstacles in learning to write argumentative; (2) the class has never been used as a research object, so it can avoid the possibility of repeated research; and (3) students' skills of Indonesian language, especially writing skills can still be improved. For information, subjects used at BIPA are a lecturer and students, comprising 10 people. Retrieval of information from students conducted by interviews and by giving the task and then those were analyzed as a data source.

Action research is a research that is the result of collaboration between researchers and teachers in order to improve the quality of learning. Arikunto (2006: 58) argues that action research is a research conducted with the aim to improve the quality of classroom practice. The principles of the implementation of action research include: (1) the efforts of the lecturer to improve the quality of learning; (2) conducted the stages of preparation, observation, and evaluation; (3) research is conducted in accordance with the groove and scientific principles; (4) the problem being addressed is a real problem in learning; (5) research aims to improve the quality of learning; and (6) learning to solve problems is not only done on the inside but also outside the classroom.

Data were collected by: (1) observation, (2) interview, (3) test, and (4) document analysis. Analysis technique was used to analyze the data that has been collected is a comparative descriptive analysis techniques and critical analysis techniques (Kelvin 2011: 65). Analysis of the data by comparing the test scores between cycles with working indicator has been set. The data of test results are classified as quantitative data. The data were analyzed descriptively, which analyzed students' test scores before using cooperative learning model and students' test scores after using cooperative learning model of three cycles. Then, the data in the form of test scores were compared to the results between cycles can achieve attainment of predetermined limits. Procedures in action research include: preparation, study / preliminary survey, implementation cycles, and the preparation of reports. The implementation cycle includes the following activities: (1) action planning; (2) action; (3) observation and interpretation; and (4) analysis and reflection.

Indicators to be achieved are the increased quality of the process and skills in multicultural vision of writing argumentative. The quality of learning can be viewed in terms of process and in terms of results. The learning process is successful if $80 \%$ of the students are actively involved, whether physical, mental, social during the learning process. In addition, students also show high enthusiasm and passion towards learning. In terms of learning outcomes is successful if $80 \%$ of students experienced a positive change and high-quality output and gain mastery in accordance with established criteria. The student is successful or completed in a multicultural vision of argumentative writing if he or she gets a score $\geq 70$.

\section{Results and Discussion}

Pre-cycles activities performed prior to the study in order to know the initial conditions of the object of study prior to the action through three steps, namely: (1) observation of the process of learning to write argumentative; (2) discussion of the problems experienced by lecturer and foreign students; and (3) the drafting process learning to write argumentative. In practice, the lecturer acted as the leader of the course learning activities, while researcher observed the learning process. At working time, many students found it difficult to find ideas, too long thought, still confused with what to write, and others. In fact, there were some students who cheated his job, but had been instructed by the lecturer to work individually. When the 
activitiy was done, the lecturer asked the students to collect their work and terminate faculty learning.

Students' performance assessment includes three indicators, namely: (1) adherence to the learning activities; (2) the activity and attention of students during learning activities; and (3) students' motivation in learning. Assessment of the argumentative writing skills was derived from the assessment of writing argumentative made by students and submitted to the lecturer at pre-action activities. This argumentative writing skills assessment covers five aspects, namely: (1) content; (2) organization; (3) vocabulary; (4) the development of language; and (5) mechanical. From the results of the assessment obtained an average score of writing the argument was 53, this result is far from standard minimum score of 70 .

The problem faced by the lecturer and students can be seen from the pre-action observation and interviews with lecturer and students. Pre-action observations results indicated that lecturers did not use innovative methods in teaching and less able to act as a friend of learning for students. Lecturer remained dominant in the classroom; there was no good interaction with the student. Lecturers could not properly carry out the learning, for example, the activities of the students delegate the task without assistance. As the students work on the assignment, the lecturer just sitting in front and did his the other job. Lecturer also did not motivate students and did not encourage students' activeness. Lecturer's weaknesses is also strengthened by the statement in an interview conducted by researchers. Lecturer said that in every learning lecturer still used conventional methods, typically with lecture method and giving assignments. Even if occasionally asking the students to work in a group, it was only used for assigning the students as a group to do the task, not to explore the thoughts of students to be more active, creative, and innovative. The problems faced by the lecturers are a serious problem. When the professor never learns using innovative methods, then forever he or she will not bring an active student. This problem arouse because the lecturer did not turn out so clearly the steps innovative methods.

Besides the lecturer, students in this pre-action also experienced some problems, in which: (1) the students did not understand about the material written arguments. This is because the lecturer did not fully explain, but students were asked to read the material itself; (2) the student did not look excited in learning because only professors lecture and assign tasks; (3) the student looked inactive in learning because the lecturer did not foster interaction between lecturer and students. Based on the results of interviews conducted with students, researcher indicate boredom towards learning. Students wanted to see change, the lesson lecturer. Based on observations and interviews of lecturer and students, researchers and professors discussed the next steps to update the learning process. The discussion talked about the methods used in learning to write argumentative, cooperative learning and teaching model. It was also discussed about the media that would be used. Cooperative learning model allows students to be more active and be able to correct each other and help between friends because this model uses the principle of discussion in small groups.

During discussion, professors and researchers also agreed to use instructional media in the form of articles as proposed by the lecturer. The investigators suggested that the selected articles are articles that are themed multicultural as seen from the writings of students who simply write the argument based on the environment around them alone. Lecturer considered that multicultural values appropriate to be applied to learning because according to the realities of the world that has a diversity of cultures, religions, ethnicities and traditions, as any student of BIPA UNS. Therefore, lecturer and researcher agreed to apply cooperative learning model coupled with multicultural vision in it at aargumentative writing class. 
Actions were taken in argumentative writing class with multicultural vision by applying cooperative learning model. Using this model, students in the group could exchange ideas with other groups, so that the insights and knowledge would be more complex and more various. The learning media used to support this model was insightful articles and videos multicultural. The use of instructional media and this model made the students becoming more active in participating in the learning process. Students were taught to find the main idea that was then made outline and developed it into writing arguments. Students were given the task to visit to another group and discussed their findings with the group. It made students active when working in groups or individually. Articles and videos were chosen as the medium of learning provided benefits to facilitate students in finding the main idea. Instructional media designed specifically for learning purposes to give benefits, such as: learning process became more obvious and attractive learning, there was interaction during learning process, improving the quality of learning outcomes and foster a positive attitude toward the process of learning and learning materials.

Main activities in this study conducted in three cycles. Based on observations and analysis on pre-action, first cycle, second cycle and third cycle can be described that there was learning improvement in writing argumentative by applying multicultural vision of cooperative learning model for the students at BIPA UNS. The improvement includes an increase in the learning process and the results of students' skills in writing arguments. The quality of the learning process in writing argumentative by applying multicultural vision of cooperative learning model could be seen by the improvement of lecturer's and the students' performance appraisal observations during the pre observation, first cycle, second cycle and third cycle.

Performance improvement of lecturer in learning activities in writing argumentative by applying multicultural vision of cooperative learning model derived from the value of lecturer in preparing lesson plans and implementing learning every action. Preparation of lesson plans by lecturers from pre observation, first cycle, second cycle and third cycle had increased. It was known based on the observations. Lecturer's performance in implementing the teaching and learning activities include a number of indicators, among others: (1) pre-learning; (2) preliminary activities; (3) main activities, including mastery of the learning material, the use of models in learning, learning activities, and assessment processes and outcomes; and (4) the closing. From the observations, it can be argued that the performance of the lecturer in carrying out learning activities improved from pre-action until the third cycle.

Performance improvement of the students during the learning process from pre-action until the third cycle can be assessed from several indicators, namely: (1) the implementation of learning activities; (2) motivation and attention of students during learning activities; and (3) students' motivation in learning. Based on observations of pre-action until the third cycle, it is known that these three indicators were increased. Learning feasibility of the students indicated by the willingness of students in performing tasks according to the instructions given by lecturer. Learning feasibility on pre-action was still low. Activity and attention of the students during learning activities ranging from pre-action up to the third cycle is always increasing. This is because students did not play an active role in learning and focused only on the lecturer. Students' motivation in learning during pre-action was still low. This value rose in the first cycle, this is due to students while performing the task appeared to have a high willingness and in accordance with lecturer's guidance. In general, the average value of the quality of the learning process, in writing argumentative by applying multicultural vision of cooperative learning model on all aspects of pre-action until the third cycle has improved.

The improvement of learning quality outcomes in writing argumentative by applying multicultural vision of cooperative learning model can be evaluated from the value of the final 
result of students' essay. The average value of students increased from pre-action until the third cycle. In cycle I, students' score were at the lower grades 40 and 80 . The number of highest average value of the first cycle was 66.5. In the second cycle the average value was 73.5 with the lowest score obtained by the student was 50 and highest score was 85 . The average value of the students in the third cycle has reached the standard minimum score 80.54 with the lowest score was 60 and the highest score was 95. For more details, the following summary table is presented the lowest value, highest value, and the average value of the student achieved.

Table recapitulation of BIPA UNS Learning Outcomes

\begin{tabular}{|ccccc}
\hline No & Pre-cycle & Cycle $\mathbf{1}$ & Cycle $\mathbf{2}$ & Cycle 3 \\
\hline $\mathbf{1}$ & 70 & 80 & 85 & 90 \\
$\mathbf{2}$ & 50 & 60 & 75 & 75 \\
$\mathbf{3}$ & 45 & 60 & 65 & 75 \\
$\mathbf{4}$ & 50 & 60 & 65 & 80 \\
$\mathbf{5}$ & 75 & 80 & 85 & 90 \\
$\mathbf{6}$ & 40 & 65 & 80 & 85 \\
$\mathbf{7}$ & 50 & 75 & 85 & 90 \\
$\mathbf{8}$ & 25 & 40 & 50 & 60 \\
$\mathbf{9}$ & 60 & 65 & 65 & 75 \\
$\mathbf{1 0}$ & 65 & 80 & 80 & 85 \\
Average Score & $\mathbf{5 3}$ & $\mathbf{6 6 , 5}$ & $\mathbf{7 3 , 5}$ & $\mathbf{8 0 , 5}$ \\
Not Pass & 2 & 4 & 6 & 9 \\
\hline
\end{tabular}

(Source: Adapted by the researcher)

Based on the final score in writing argumentative by applying multicultural vision of cooperative learning model, it is known that the percentage of successful students score $>70$ (complete) and students whose score was $<70$ (unfinished). From the table above, it can be seen that: (1) the percentage of students who completed the pre-action were $20 \%$ ( 2 people) and students who had not completed $70 \%$ (7), (2) the percentage of students who pass in the first cycle were $40 \%$ (4 students) and who had not completed were $60 \%$ (6 students), (3) the percentage of students who pass in the second cycle were 60\% (60 students) and who had not completed were $40 \%$ (4 students), and (4) the percentage of students who were completed in the third cycle were $90 \%$ (9 students) and who had not completed was $10 \%$ ( 1 student). The success of this study also reflected in some of the studies that have been conducted by Saddhono (2012, 2013, 2014, and 2015).

This study turned out to be in line with the study by researchers in the field of multicultural (Iwai, 2013; Hund, 2012; Gay, 2013; O'Byrne: 2015) who studied in schools and higher education. This study is relevant because BIPA learner can be compared to learning in primary and secondary school level. As for the writing skills of argument also has been studied by researchers who give the conclusion that writing argumentation is the kind of writing that is quite difficult. Therefore it is necessary strategies to give the material the writing skills of argument (Schneer, 2014; Ritchie, 2012). The application of the model and learning strategies undertaken to improve the learning process and results. improvement of process and learning outcomes is the goal of this research. The focus of every classroom action research is the increase. 


\section{Conclusions}

The implementation of cooperative learning models can improve the quality of the learning process, multicultural vision of argumentative writing at BIPA UNS. The improvements include: (1) adherence to the learning activities by students were shown the willingness in performing their duties; (2) the activity and attention of students during learning; and (3) increasing students' motivation in learning. Improvement of the students' skills can be seen from the increase in value of the average student in each cycle. This study suggests that the success of the process and learning outcomes are influenced by several factors, including lecturer, students, learning models, learning media and learning resources. The use of models and innovative learning techniques supported by the use of a variety of media and is associated with a real-life feel more exciting and effective way to improve the quality of learning. Overall, the findings in this study imply that in order to improve the writing skills of the student's argument, a model of cooperative learning can be used as an alternative learning to replace conventional learning models that have been applied to the lecturer. In practice, it needs to be considered the systematic work procedure, focusing in a problem-solving process, involving students in decision-making and training students to produce ideas and work independently. By implementing innovative learning model will surely provide improvement process and results both from the lecturer and students.

\section{Acknowledgements}

The author expressed his gratitude to the Indonesian Endowment Fund for Education (LPDP), the Ministry of Finance, the Republic of Indonesia, which has funded this research. Thanks are also extended to SEAMEO Qitep in Language, ADOBSI, LPPM UNS, and others. Acknowledgements also to the members of this research Muhammmad Rohmadi and Chafit Ulya who has supported the implementation of this research.

\section{References}

Arikunto, Suharsimi; et al. 2006. Penelitian Tindakan Kelas. Jakarta: PT Bumi Aksara

Djuharie, O. Setiawan and Suherli. 2001. Panduan Membuat Karya Tulis. Bandung: Yama Widya

Gay, Geneva. 2013. Cultural Diversity and Multicultural Education. Curriculum Inquiry, 43(1): 48-70

Hasyim, Dardiri and Hartono, Yudi. 2008. Pendidikan Multikultural di Sekolah. Surakarta: Sebelas Maret University Press

Huda, Miftahul. 2012. Cooperative Learning. Yogyakarta: Pustaka Pelajar

Hurd, Ellis. 2012. A Framework for Understanding Multicultural Identities: An Investigation of a Middle Level Student's French-Canadian Honduran-American (Mestizo) Identity. Middle Grades Research Journal, 7(2): 111-127

Iwai, Yuko. 2013. Multicultural Children's Literature and Teacher Candidates' Awareness and Attitudes Toward Cultural Diversity. International Electronic Journal of Elementary Education, 5(2) 185-198

O'Byrne, W. Ian; Smith, Shane A. 2015. Multicultural Education and Multiliteracies: Exploration and Exposure of Literacy Practices with Preservice Teachers. Reading \& Writing Quarterly, 31(2): 168-184

Mahfud, Choirul. 2008. Pendidikan Multikultural. Yogyakarta: Pustaka Pelajar

Maslikhah. 2007. Quo Vadis Pendidikan Multikultur. Surabaya: PT. Temprina Media Grafika

Rector. 2016. Internationalization of Sebelas Maret University Based on National Culture: Rector's Report in Order Lustrum 8 Sebelas Maret University. Surakarta: Sebelas Maret University.

Ritchie, Mathy; Black, Catherine. 2012. Public Internet Forums: Can They Enhance Argumentative Writing Skills of Second Language Learners?. Foreign Language Annals, 45(3): 349-361

Saddhono, Kundharu, 2012. Kajian Sosiolingustik Pemakaian Bahasa Mahasiswa Asing dalam Pembelajaran Bahasa Indonesia untuk Penutur Asing (BIPA) di Universitas Sebelas Maret. Kajian Linguistik dan Sastra, 24(2): 176-186 
Saddhono, Kundharu. 2013. Model Pembelajaran Kooperatif Teknik Student Teams Achievement Divisions (STAD) untuk Meningkatkan Keterampilan Menulis Narasi Mahasiswa Asing di Universitas Sebelas Maret. In The $3^{\text {rd }}$ International Seminar Language Maintenance and Shift: Semarang, 2-3 July 2013: Postgraduate of Linguistics, Diponegoro University

Saddhono, Kundharu, 2014. A Sociolinguistics Study on the Use of the Javanese Language in the Learning Process in Primary School in Surakarta, Central Java, Indonesia. International Education Studies, 7(6): 25-30

Saddhono, Kundharu. 2015. Integrating Culture in Indonesian Language Learning for Foreign Speakers at Indonesian Universities. Journal of Language and Literature, 6(2): 349-353

Schneer, David. 2014. Rethinking the Argumentative Essay. TESOL Journal, 5(4): 619-653

Sugiyanto. 2009. Model-model Pembelajar Inovatif. Surakarta: Yuma Pustaka

Suparno and Yunus, Mohamad. 2006. Keterampilan Dasar Menulis. Jakarta: Universitas Terbuka

Yamin, Martinis. 2011. Paradigma Baru Pembelajaran. Jakarta: Gaung Persada Press 